\section{FRI0002 IL-1 RECEPTOR ANTAGONIST (IL-1RA) TREATMENT IS ASSOCIATED WITH IMPROVEMENT OF ANAEMIA IN RHEUMATOID ARTHRITIS}

1J Kay, ${ }^{2} \mathrm{~S}$ Bryant, ${ }^{3} \mathrm{MW}$ Cravets, ${ }^{4} \mathrm{D}$ McCabe. ${ }^{1}$ Department of Rheumatology, Lahey Clinic, Burlington; ${ }^{2}$ Extramural Research; ${ }^{3}$ Department of Biostatistics; ${ }^{4}$ Clinical Research, Amgen Inc., Thousand Oaks, USA

\subsection{6/annrheumdis-2001.1131}

Background Anaemia occurs frequently as an extraarticular complication of rheumatoid arthritis (RA) and usually correlates with markers of disease activity. Interleukin (IL)-1, levels of which are elevated in serum and synovial tissue of patients with RA, inhibits erythropoiesis in vitro. Serum IL-1 levels are higher in anaemic patients with RA than in those without anaemia. ${ }^{1}$

Objectives To determine if IL-1 receptor antagonist (IL-1ra) is associated with improvement of anaemia in patients with rheumatoid arthritis.

Methods We observed the effect of daily IL-1ra treatment in anaemic patients with active, severe RA who were enrolled in a 24-week, double-blind, randomised, placebo-controlled multicenter study of IL-1ra therapy. Fifty (14.2\%) of the IL-1ra-treated patients and $13(10.7 \%)$ of the placebo-treated patients were anaemic, defined as HCT $<=34 \%,{ }^{2}$ upon initiation of drug therapy.

Results Improvement in anaemia was stratified according to the increase after 24 weeks of treatment. Although the number of anaemic patients enrolled in this trial was small, more patients treated with IL-1ra exhibited improvement in HCT after 24 weeks of drug than did patients receiving placebo:

\begin{tabular}{|c|c|c|c|c|c|}
\hline & $\begin{array}{l}\text { Placebo } \\
(\mathrm{N}=13)\end{array}$ & $\begin{array}{l}\text { IL-1ra } 30 \mathrm{mg} \\
(\mathrm{N}=17)\end{array}$ & $\begin{array}{l}\text { IL-1ra } 75 \mathrm{mg} \\
(\mathrm{N}=17)\end{array}$ & $\begin{array}{l}\text { IL-1ra } 150 \mathrm{mg} \\
(\mathrm{N}=16)\end{array}$ & $\begin{array}{l}\text { Total IL-1ra } \\
(\mathrm{N}=50)\end{array}$ \\
\hline$>$ = 3 vol- $\%$ & $2(15.4 \%)$ & $10(58.8 \%)$ & $6(35.3 \%)$ & $5(31.3 \%)$ & $21(42.0 \%)$ \\
\hline$>=5$ vol- $\%$ & $1(7.7 \%)$ & $3(17.6 \%)$ & $4(23.5 \%)$ & $2(12.5 \%)$ & $9(18.0 \%)$ \\
\hline$>=6$ vol- $\%$ & $1(7.7 \%)$ & $2(11.8 \%)$ & $4(23.5 \%)$ & $1(6.3 \%)$ & $7(14.0 \%)$ \\
\hline
\end{tabular}

Conclusion Anaemia improved in patients taking each of the 3 doses of IL-1ra. Interestingly, 3 of the 7 IL-1ra-treated patients with $>=6$ vol- $\%$ improvement in their HCT did not meet ACR20 response criteria. Thus, IL-1ra therapy may improve anaemia in RA patients independently of its effect on articular disease activity. Further study of IL-1ra therapy in anaemic patients with RA is warranted to clarify its effects on erythropoiesis and the impact of these changes in Hct on clinical status.

\section{REFERENCES}

1 Maury, et al. Ann Rheum Dis. 1988:47:972

2 Pincus, et al. Am J Med. 1990;89:161

\section{FRI0003 HIGH DOSE CHEMOTHERAPY WITHOUT AUTOLOGOUS STEM CELL REINFUSION IN THE TREATMENT OF RA}

KD Pile, M Rischmueller, L Milazzo, W Jaksic, N Wickham. Departments of Rheumatology and Haematology, Adelaide University Department of Medicine, TQEH, Adelaide, Australia

\subsection{6/annrheumdis-2001.1132}

Background With increasing use of high dose cytotoxic chemotherapy with autologous peripheral blood stem cell (APBSC) rescue for the treatment of severe autoimmune diseases, including
RA, there is concern that the reinfusion of auto-aggressive T cells may reactivate the autoimmune process. High dose chemotherapy without the reinfusion of autologous stem cells permits a form of in vivo $\mathrm{T}$ cell depletion and stem cell selection that obviates the reinfusion of auto-aggressive $T$ cells.

Objectives Evaluation of medium term outcome in patients undergoing high dose chemotherapy without autologous stem cell reinfusion in patients with severe RA.

Methods Three patients with RA and one with JRA, which was progressive and severe despite multiple DMARDs, were treated with Cyclophosphamide $50 \mathrm{mg} / \mathrm{kg}$ for four consecutive days, with G-CSF $300 \mathrm{mcg}$ bd commencing from day five. Prior to this, APBSC were collected following priming with Cyclophosphamide and G-CSF. The APBSC were not intended for reinfusion unless prolonged cytopenias or severe infection occurred. DMARDs were discontinued at the time of high dose chemotherapy and low to moderate dose prednisolone was commenced in all patients. Immunophenotyping of lymphocyte subsets was performed to monitor immune regeneration.

Results High dose cyclophosphamide was well tolerated and all patients achieved haematological recovery without the need for APBSC reinfusion. Median time to neutrophil recovery (ANC $>500 /(\mathrm{L})$ and platelet transfusion independence was 17 and 16 days, respectively. All patients required antibiotics for neutropenic fever for between $2-8$ days.

Absolute change and\% change from baseline at 6 and 12 months is shown in the Table 1 . All subjects have required recommencement of a DMARD between 6 and 12 months post therapy. One patient, who had been taking long term oral steroids, developed bilateral avascular necrosis of the femoral heads.

\begin{tabular}{|c|c|c|c|c|}
\hline & Patient 1 & Patient 2 & Patient 3 & Patient 4 \\
\hline ESR mm/hr & $\begin{array}{l}80,80 \%: 70 \\
70 \%\end{array}$ & $\begin{array}{l}10,150 \%: 5 \\
25 \%\end{array}$ & $\begin{array}{l}80,66 \%: 15 \\
12 \%\end{array}$ & $\begin{array}{l}0,0 \%: 40, \\
44 \%\end{array}$ \\
\hline mHAQ & N/A: $4,100 \%$ & $+1: 0,0 \%$ & $2,13 \%: 1,6 \%$ & N/A: $0,0 \%$ \\
\hline VAS pain - mm & N/A: $74,97 \%$ & $\begin{array}{l}51,221 \%: 21, \\
50 \%\end{array}$ & $\begin{array}{l}51,94 \%: 12, \\
122 \%\end{array}$ & $\begin{array}{l}\text { N/A: } 69, \\
97 \%\end{array}$ \\
\hline $\begin{array}{l}\text { VAS quality of life } \\
-\mathrm{mm}\end{array}$ & N/A: $53,96 \%$ & $0,0 \%: 2,4 \%$ & $\begin{array}{l}47,52 \%: 43, \\
47 \%\end{array}$ & $\begin{array}{l}\text { N/A: } 27, \\
90 \%\end{array}$ \\
\hline
\end{tabular}

Absolute and $\%$ change from baseline at 6 and 12 months post therapy ( $<100 \%$ equals $\%$ improvement).

Conclusion Whilst high dose chemotherapy without stem cell reinfusion may be considered as a therapeutic option in cases of severe progressive rheumatoid arthritis, further research in maintaining the initial benefit is required.

\section{FRI0004 VITAMIN D3 ANALOGUE - ALPHACALCIDIOL DECREASES IL1, TNF AND ANTIOXYDANT ENZYMES ACTIVITY IN RA AND JRA PATIENTS}

${ }^{1} \mathrm{~J}$ Vojinovic, ${ }^{2} \mathrm{~N}$ Pejnovic, ${ }^{3} \mathrm{~A}$ Stankovic, ${ }^{1} \mathrm{M}$ Cosic. ${ }^{1}$ Clinic of Pediatrics; ${ }^{2}$ Department Exp. Med., MMA, Belgrade, Yugoslavia; ${ }^{3}$ School of Medicine, University Nis, Nis

\subsection{6/annrheumdis-2001.1133}

Background In recent years immunomodulatory action of vitamin D3 was clearly confirmed, when its used in high doses. 1- 